\title{
Management Competencies and Organizational Performance in CEE: A Comparison of Slovenia and Austria
}

\author{
Petra Šparl ${ }^{1}$, Anja Žnidaršič ${ }^{1}$, Helmut Kasper ${ }^{2}$, Jürgen Mühlbacher ${ }^{2}$, Jure Kovač ${ }^{1}$ \\ ${ }^{1}$ University of Maribor, Faculty of Organizational Sciences, Kidričeva 55a, 4000 Kranj, \\ petra.sparl@fov.uni-mb.si, anja.znidarsic@fov.uni-mb.si, jure.kovac@fov.uni-mb.si
}

${ }^{2}$ WU - Vienna University of Economics and Business, Institute for Change Management and Management Development, Welthandelplatz 1, A-1090 Vienna, Austria, helmut.kasper@wu.ac.at, juergen.muehlbacher@wu.ac.at

\begin{abstract}
Today management competencies are seen as the only long-term strategic advantage of any company. However, from corporate experience we know that only $10 \%$ of the knowledge acquired is transferred into entrepreneurial practice. Current trends in management development often overemphasize individual learning and ignore the missing fit between individual behavior and organizational performance.

To meet these demands, we collected competency attributions of managers attending executive courses in Austria and Slovenia. A questionnaire with closed and open question will help to explore and compare the relation between organizational performance and current management competencies in these countries. The results confirm our predictions to a lesser extent. However, they represent a basis for further examination of the relationship between managerial competencies and organizational performance.
\end{abstract}

Keywords: classes of competencies, competency-based theory, competency management, organizational performance

\section{Introduction}

In the theory and practice of management, the question of key success factors in the development of a company's sustainable competitive advantages has been raised consistently. That is, whether the key factors are internal or external or a combination of both. Along with the question about the factors leading to the development of sustainable competitive advantages of a company, research is also conducted in this field.

Literature reveals numerous more or less extensive research works on the key success factors of a company. Below, you will find the results of two research studies conducted in the mentioned field. The first study is an extensive ten year research project entitled "The Evergreen Project", which was carried out by Nitin Nohria and colleagues (2003). The fundamental goal of this project was to answer two questions: "Why do some companies consistently outperform their competitors?" and "Which of the hundreds of well-known business tools and techniques can help a company be great?" (Nohria et al., 2003, p. 42). In their conclusion, Nohria and colleagues formed the following list of behaviors and manage- ment practices that support excellence in each practice. The practices were divided into primary and secondary management practices (Nohria et al, 2003). Primary management practices include: to devise and maintain a clearly stated, focused strategy; develop and maintain flawless operational execution; develop and maintain a performance-oriented culture; and to build and maintain a fast, flat organization. Whereas, the secondary management practices include: holding on to talented employees and finding more; making industry-transforming innovations; finding leaders who are committed to the business and its people; and seeking growth through mergers and partnerships.

A similar, but less extensive research study was carried out by Stadler and Wältermann (2012) and entitled "The Century Champions". They made a detailed analysis of the commercial practices of the largest and above-average performing European companies established before 1904 hence, companies that have left behind over a 100 years of successful development and operations. In their research, the authors identified five key factors that were typical of successful companies, i.e., an efficient use of the existing resources,

Received: $31^{\text {st }}$ August 2013; revised: $17^{\text {th }}$ September 2013; accepted: $26^{\text {th }}$ September 2013 
diversification within the business lines known, successful management of the learning process, risk management and a conservative financial policy, and successful change management, particularly the management of changes in organization culture (Stadler \& Wältermann, 2012).

The results indicated above allow us to sum up that the authors of both research studies identified the operations of managers and their capabilities related to the use and association of company resources as the key factor in the development of a company's competitive advantages. These findings can also be constrained theoretically using a theory that has recently become very popular when explaining a company's competitive advantages, i.e. the competency-based theory. This theory is based on a claim that the operations of the management focused on identifying and developing the company's key competencies that provide long-term competitive advantages are vital for the achievement of the company's competitive advantages. As stated by Probst et al. (2000), managers can develop a company's competencies on three levels in order to achieve competitive advantages:

- on an individual level by developing the competencies of an individual manager,

- on an organizational level by linking individual competencies to organizational competency clusters, and

- on an inter-organizational level by linking individual parts of the company and promoting and supporting cooperation between companies.

We next discuss the dimensions of the competency-based theory, which represent the fundamental theoretical frame for our empirical research.

\section{Competency-based theory}

Although competency movement "became popular in early 1990s with works produced by authors, such as Prahalad and Hamel (1994), Sanche et al. (1996), Teecce et al. (1997)" (Freiling 2004, p.28), several articles highlighting the competency-based theory were published much earlier. In his contribution "Evolutionary and competency-based theories of the firm", Hodgson (1998) cited the following works in competency-based theory as pioneers: Frank Knight (1921), Edith Penrose (1959), George Richardson (1972) as well as Richard Nelson and Sidney Winter (1982). Furthermore, he summarized his deliberations by stating that "the competencies paradigm has attracted a wide and growing following and its ideas are now prominent in the literature on corporate strategy" (Hodgson, 1998, p. 25). He also added that "the competencybased approach has links with similar approaches in a number of allied areas, including technology studies and international business" (Hodgson, 1998, p. 25) and stressed the extent and popularity of the competency-based theory today.

There is no doubt that the bases for the conceptual design of the competency-based theory can be found in the resourcebased theory. In particular, this refers to the work produced by Jay Barney (1991). Despite the apparent relationship between the resource-based and competency-based theory, there are still major differences between them. Hence, Dierichx and Cool (1989) stated: "a key difference between the resource and competency-based view is the chain of causality: Whereas the resource-based view concludes that superior resources will cause performance differences among firms, the competencybased view prefers a more subtle reasoning. Homogeneous assets and heterogeneous resources are the starting point of the chain. However, the resource endowment is not enough in order to explain performance differences. The firm itself has to be in a position to make use of these resources in a goal- and market-oriented way" (Freiling, 2004, p. 31). At this point, the competency-based view steps in with its further explanation of the way to achieve competitive advantages, thus, supplementing and upgrading the resource-based perspective.

Another difference between the mentioned theories lies in the fact that "firm-specific competencies do not necessarily refer to internal resources" (Freiling, 2004, p. 32). The competency-based view is, therefore, also based on the concept of open boundaries. As stressed by Lorenzoni and Lipparini (1999), "this gives rise to the impression that sustaining competitive advantages very often rest on the assets of network of the firms and even more, on blending own capabilities with the ones of partner firms" (Freiling, 2004, p. 32).

Further important contributions in the field of the competency-based theory have focused on strategic management, such as Prahalad and Hamel (1990), who developed a core competency concept and Teece et al. (1997) with their explanation of the dynamics of competencies in the process of strategic planning and the building of corporate competitive advantages.

\subsection{Competency Management and Performance}

Since the beginning of competency management, nearly all authors have stated a positive relationship between management competencies and success. Boyatzis (1982) argued in his seminal book on competency and performance, that the competency clusters "Goal and Action Management", "Leadership", and "Human Resource Management" are the most important ones. Prahalad and Hamel (1990) distinguished between technological and management competencies and only the fit of both will lead to entrepreneurial success. Following these findings, the assessment center movement only focused on company-specific bundles of competencies to explain success and failure (Woodruffe, 1993). After that Bartlett and Goshal (1997) tried to find typical clusters of competency for any hierarchical level and McCall (1998) focused on the relationship between competency and corporate strategy as the crucial factor for success. More recent literature like Heyse and Erpenbeck (2004), Mühlbacher (2007), Erpenbeck and von Rosenstiel (2007) or Kauffeld et al. (2009) have offered multiple-job-models to emphasise the fact that competencies are strongly oriented towards the future. This enables a person or company to tackle upcoming challenges, whose nature cannot be predicted or determined, in a self-organized manner.

But most of these models - except Boyatzis (1982) - do not offer any empirical evidence concerning the relationship between competency management and corporate performance. Therefore this explorative study tries to give an answer to the 
following research question: "Which management competencies are influencing the turnover or profit of a company? A comparison of Austria and Slovenia."

\subsection{Classes of Competencies}

To answer this question, we had to first define the different classes of competencies. Therefore the following will give a short overview concerning the theoretical development of the classes of competencies and this will lead us to the model used for the empirical research. An early differentiation of competencies was made by Jacobs (1989, p. 36), who distinguishes between "hard and soft competencies". Hard competencies refer, for example, to analytical and organizational capabilities, while creativity and sensitivity are soft competencies. From this, Jacobs (1989) develops the argument that hard competencies result in observable behavior, with the invisible but dominant soft competencies underlying them. The principles of this conviction, though conceivable, are difficult to prove and, thus, this conception has been classified as an artificial differentiation with low explanatory potential in the theoretical discussion (Woodruffe, 1993).

To avoid this criticism, a categorization of the knowledge, capabilities, properties and abilities required has prevailed: first, consisting of three - still without the category of self- and personal competency (Sloane 1998) - and later four areas of competency, which meet both the theoretical and pragmatic requirements (Heyse, 1997). A clearer description of these four classes of competencies can be found in Sonntag and Schaper (1999).

All these categorizations have been reworked. In newer classifications, for instance, functional and methodological competencies are combined, because of their proximity and the desired generation of a general competency model, which separates self-dispositive actions from personal dispositions and introduces the new class, i.e., that of leadership competency. As a result, the following five classes of competencies can be distinguished: (Kasper et al. 2005)

- Self-dispositive competencies, which represent the selforganized use of one's own resources (time, know-how etc.)

- Methodological competencies, comprising all analytical and solution-oriented behaviors

- Social-communicative competencies, covering the area of social interaction (excluding leadership)

- Leadership competencies, including the full range of leadership, motivation and personnel development

- Personal competencies, mainly manifesting themselves in extraordinary personality traits

In the following, we will have a look at these five classes of competencies and their impact on the corporate performance.

\section{Methodology}

The fundamental objective of our research was to discover the link between managerial competencies and organizational performance. For this first explorative study, questionnaires are based on eight closed questions. Five questions focus on the above mentioned classes of competencies, which are rated on a 6-point Likert type scale of importance, where 1 means "not important at all" and 6 means "very important". If one competency class is rated higher than four, the respondents will be asked to name the most important competency in this field. Furthermore, the proportional change of human resources within the last two years has been asked for as independent variable and the proportional changes of turnover and profit within the last two years were taken as dependent variables.

Data were collected from 27 Austrian managers and 55 Slovenian managers attending either an executive MBA at the WU Vienna University of Economics and Business or different executive courses at the University of Maribor, Faculty of Organizational Sciences. The explorative study was conducted in spring 2012. Due to mostly insignificant results for the Slovenian study (see Table 3), we decided to conduct a second more comprehensive study.

Data for this study were collected from Slovenian enterprises in June 2013 using a revised questionnaire. Therefore, instead of only five questions focusing on the five classes of competencies, we decided to include several questions within particular classes of competencies, such that each question is focusing on each individual competency, defined by Kasper and colleagues (2005). Consequently, we did not ask respondents to name the most important competency if the class was rated higher than four.

The anonymous questionnaires were sent to 216 postmail and to 738 e-mail addresses, using the Slovenian online survey portal $1 \mathrm{ka}$. The sample was selected as a quota sample according to the proportion of the main activity of the enterprises. In each activity class, enterprises were randomly selected from PIRS - the business register of Slovenia. Among all mails sent, three letters and 66 e-mails were not delivered, because of different reasons such as wrong address, non-existing company etc. Additionally, questionnaires were sent to the 100 top Slovenian managers (according to the Slovenian magazine Manager (Top 100, 2013)). After two re-calls we received 214 completed questionnaires, therefore the overall response rate was equal to $22.3 \%$.

Overall, $62 \%$ of respondents were male and $38 \%$ female. Among them, $76 \%$ were presidents or members of the board, $15 \%$ department managers and $9 \%$ without leadership function. Further, 54\% organizations had less than 10 employees, $21 \%$ between 10 and $49,8 \%$ between 50 and 149 and $17 \%$ more than 150 employees. For $43 \%$ companies the main business activity was services, for $23 \%$ trade, for $8 \%$ industry, for $5 \%$ education and science, for $4 \%$ health and social care, for $3 \%$ state or municipality, for $2 \%$ banking or insurance and for $12 \%$ companies other business activities. In the following section, we illustrate some descriptive statistics and regression models.

\section{Results and Discussion}

In order to compare the results of the first with those of the second study, the mean values for each class of competencies were computed in the latter. Again, we point out that in the 
first study the questionnaires consisted of five questions for five classes of competencies, while in the second study every class of competencies consisted of several individual components (questions). Since we wanted to compare the results with the first study, the mean values for each class of competencies were computed for the second study. The results are presented below.

\subsection{Results}

We found out that respondents of both studies estimated the importance of all five classes very highly, although there were minor differences between results. In the first study, the average of competency importance range between 4.12 and 5.04 (see Table 1) and managers of both countries estimated Methodological competencies as the most important ones $(\bar{x}(A)=4.85, s(A)=0.83$ and $\bar{x}(S I)=\mathbf{5 . 0 4}, s(S I)=0,84)$. In the second Slovenian study, class means of all competencies ranged between 4.82 and 5.39 (see Table 2), and Leadership was selected as the most important one $(\bar{x}=\mathbf{5 . 3 9}, \mathrm{s}=0.59)$.

Especially in the second Slovenian study, high importance values yield negatively skewed distribution for all competen- cies (Table 2), which means that it won't be easy to obtain a significant multiple regression model.

\section{Regression models}

In the first step of both studies, regression models were built, containing the ratings of the five classes of competencies and the proportional change of human resources as independent variables and proportional change in profit as dependent one. No significance was found in the first study from both study groups. Neither for the Austrian nor the Slovenian data any significant results could be found in the first study. Similarly, no significant model could be found in the second study. The authors would like to explain these with respect to strategic balance-sheet decisions and matters of taxations.

After replacing the proportional change in profit by the proportional change in turnover, the Austrian regression model showed a highly significant $(\mathrm{p}=0.001)$ result, explaining nearly two thirds of the spread $\left(R^{2}=0.612\right)$. The Slovenian data from the first study does not show any significance $(\mathrm{p}$ $=0.437)$. For the data from the second Slovenian study we obtain a significant model $(\mathrm{p}<0.001)$ which explains $71 \%$ of the variation of turnover $\left(R^{2}=0.71\right)$. Table 3 gives an overview regarding the independent input variables in detail.

Table 1: Descriptive statistics for the first study in both countries (A, SI)

Competencies

\begin{tabular}{|c|c|c|c|c|c|c|c|c|c|c|c|c|c|}
\hline & \multicolumn{2}{|c|}{ Methodological } & \multicolumn{2}{|c|}{$\begin{array}{c}\text { Social- } \\
\text { commun. }\end{array}$} & \multicolumn{2}{|c|}{ Leadership } & \multicolumn{2}{|c|}{$\begin{array}{c}\text { Self- } \\
\text { dispozitive }\end{array}$} & \multicolumn{2}{|c|}{ Personal } & \multicolumn{2}{|c|}{ HR* } \\
\hline & & & SI & $\mathrm{A}$ & SI & $\mathrm{A}$ & SI & A & SI & $\mathrm{A}$ & SI & $\mathrm{A}$ & SI \\
\hline \multirow{2}{*}{$\mathrm{N}$} & Valid & 33 & 57 & 33 & 57 & 33 & 57 & 32 & 57 & 33 & 57 & 30 & 57 \\
\hline & Missing & 0 & 0 & 0 & 0 & 0 & 0 & 1 & 0 & 0 & 0 & 3 & 0 \\
\hline \multicolumn{2}{|c|}{ Mean } & 4.85 & 5.04 & 4.67 & 4.70 & 4.33 & 4.75 & 4.28 & 4.21 & 4.12 & 4.28 & 3.01 & -7.61 \\
\hline \multicolumn{2}{|c|}{ Std. Deviation } & 0.83 & 0.84 & 0.69 & 0.91 & 0.89 & 0.93 & 0.85 & 1.05 & 0.96 & 1.00 & 7.79 & 111.81 \\
\hline \multicolumn{2}{|c|}{ Skewness } & -0.39 & -0.62 & -0.05 & -0.56 & -0.17 & -1.27 & 0.07 & -0.34 & -0.26 & -0.26 & -0.13 & -6.50 \\
\hline \multicolumn{2}{|c|}{ Kurtosis } & -0.20 & -0.10 & -0.06 & 0.36 & -0.87 & 3.59 & -0.58 & -0.31 & -0.88 & 0.01 & 2.18 & 47.07 \\
\hline
\end{tabular}

*...HR - proportional change in human resources

Table 2: Descriptive statistics for the second study

Competencies

\begin{tabular}{|l|l|c|c|c|c|c|c|}
\hline \multicolumn{2}{|c|}{} & $\begin{array}{c}\text { Methodological } \\
\text { (class mean) }\end{array}$ & $\begin{array}{c}\text { Social-commun. } \\
\text { (class mean) }\end{array}$ & $\begin{array}{c}\text { Leadership } \\
\text { (class mean) }\end{array}$ & $\begin{array}{c}\text { Self-dispozitive } \\
\text { (class mean) }\end{array}$ & $\begin{array}{c}\text { Personal } \\
\text { (class mean) }\end{array}$ & \begin{tabular}{c} 
HR* \\
\multirow{2}{*}{ N }
\end{tabular} \\
\cline { 2 - 8 } & Valid & 195 & 194 & 192 & 189 & 191 & 161 \\
\hline \multirow{2}{*}{ Mean } & 25 & 26 & 28 & 31 & $\mathbf{5 . 1 5}$ & $\mathbf{5 . 2 9}$ & $\mathbf{1 . 8 5}$ \\
\hline Std. Deviation & $\mathbf{4 . 8 2}$ & $\mathbf{4 . 8 7}$ & $\mathbf{5 . 3 9}$ & 0.61 & 0.57 & 23.60 \\
\hline Skewness & -0.67 & 0.68 & 0.59 & -1.15 & -1.29 & 1.65 \\
\hline Kurtosis & 1.03 & -0.77 & -2.04 & 2.74 & 3.29 & 14.10 \\
\hline
\end{tabular}


Table 3: Regression models for Austrian (A) and both Slovenian Studies (SI-1 and SI-2)

\begin{tabular}{|l|c|c|c|c|c|c|}
\hline \multirow{2}{*}{ Model } & \multicolumn{2}{|c|}{ A } & \multicolumn{2}{c|}{ SI - 1 } & \multicolumn{2}{c|}{ SI - 2 } \\
\cline { 2 - 7 } & Beta & $\boldsymbol{p}$ & Beta & $\boldsymbol{p}$ & Beta & $\boldsymbol{p}$ \\
\hline (Constant) & & 0.423 & & 0.93 & & 0.68 \\
\hline Methodological (class mean) & -0.20 & 0.21 & 0.284 & 0.081 & -0.05 & 0.48 \\
\hline Social-communication (class mean) & -0.12 & 0.54 & -0.059 & 0.767 & 0.09 & 0.21 \\
\hline Leadership (class mean) & 0.50 & 0.01 & -0.171 & 0.343 & -0.02 & 0.80 \\
\hline Self-dispozitive (class mean) & 0.22 & 0.24 & -0.052 & 0.775 & -0.07 & 0.39 \\
\hline Personal (class mean) & -0.01 & 0.97 & -0.042 & 0.812 & 0.07 & 0.36 \\
\hline Prop. Change in human resources & 0.53 & $0.00^{*}$ & 0.223 & 0.115 & 0.83 & $0.00^{*}$ \\
\hline Model summary & \multicolumn{2}{|l|}{$R^{2}=0.61, p=0.001$} & $R^{2}=0.11, p=0.44$ & $R^{2}=0.71, p=0.00^{*}$ \\
\hline
\end{tabular}

Dependent Variable: Proportional change in turnover; ${ }^{*} \mathrm{p}<0.001$

Table 3 shows that it is evident that the Austrian regression model shows significant results concerning leadership competencies and the proportional change in human resources for an increasing turnover. The ranking of the open questions as stated in the description of the questionnaire before - shows following results for the competency class of leadership: motivation \& empowerment was stated 25 times as most important competency, leadership 10 times and HR development 3 times. Therefore, these results offer the explanation that in a growing and motivating environment, even in times of crisis, strategic competency management focusing on leadership competencies will help to improve corporate performance.

Unfortunately, the analysis of the first Slovenian data with proportional change in turnover as dependent variable also does not show any significances. The regression model itself $(p=0.437)$ and also the variables (see Table 3$)$ are far away from an "at least acceptable" result. Only methodological competencies and the change in human resources might offer some starting points for further analysis.

From the second study we obtained a significant model that has only one significant predictor i.e., the proportional change in human resources. All other variables are far from being significant. Because we only got one significant variable, we also built a simple regression model with proportional change in turnover as a dependant variable and proportional change in human resources as the only independent variable. We again obtain a significant model that explains $70 \%$ of the variation of turnover (see Table 4 ), which means that all other variables show a negligible impact on turnover.

Table 4: Coefficients for the second Slovenian simple regression model.

\begin{tabular}{|l|c|c|}
\hline Model & Beta & $\boldsymbol{p}$ \\
\hline (Constant) & & 0.57 \\
\hline Human resources & 0.84 & $0.00^{*}$ \\
\hline
\end{tabular}

Dependent Variable: Change in turnover;

$R^{2}=0.70 * \mathrm{p}<0.001$
As the Austrian model also depicts leadership as a significant variable, we checked for outliers in the Slovenian second study and tried to get a multiple regression model without $5 \%$ of the most extreme values. Even omitting those values, we were not able to obtain a significant model with significant predictors other than human resources for none of the dependent variables: proportional change in profit and proportional change in turnover.

\section{Conclusion}

The research studies and articles focusing on the study of the relationship between managerial competencies and organizational performance are scarce. In order to fill the void in this field, three empirical studies were conducted using a questionnaire that was based on eight closed questions. Five questions focused on the above mentioned classes of competencies, which were rated on a 6-point Likert type scale. Furthermore, the proportional change of human resources within the last two years was asked for as an independent variable, whereas proportional changes of turnover and profit within the last two years were taken as dependent variables. In this study, we used the competency model of Kasper et al. (2005) and included 27 Austrian managers and 55 Slovenian managers in spring 2012. Due to mostly insignificant results for the Slovenian study, we decided to conduct a second, more comprehensive study. Data for this study were collected among Slovenian enterprises in June 2013 and included 214 Slovenian managers.

Unfortunately, the goals set at the beginning of the research were not achieved. The results did not bring a clear answer to the question "Which managerial competencies are crucial for achieving organizational performance?". Only the Austrian sample reveals a link between human resources, leadership and turnover. The results of both Slovenian studies, however, did not bring the desired answers. In our opinion, the results for Slovenia are a reflection of the not yet concluded structural reforms in the Slovene economy and other organizations. All functions of the management are viewed highly important, which shows a low level of professionalization of manage- 
ment and an undifferentiated understanding of managerial competencies.

The current research results allow us to draw the following conclusions. Firstly, it may be concluded, although this was not the goal of the research, that all five classes of competencies that were included in our model were estimated very highly with the lowest mean in the 6-point importance scale being 4.12. High values of individual competencies prove that the competency model established is correct. Secondly, the relationship between competency and organizational performance that was found in the Austrian study stresses leadership as the key competency in management in times of crisis in the economy and society. Similar findings have been reached by the Edelman Berland consulting firm (2013), which has been carrying out an extensive study on trust, the so-called Edelman Trust Barometer, for over a decade. Presenting the final 2013 research report on the level of global trust, Richard Edelman, the President and CEO, said: "We're clearly experiencing a crisis in leadership," (www.edelmanberland. com/press-releases/2013-edelman-trust-barometer-finds-acrisis-in-leadership). This statement summarizes the findings from their research on the trust expressed in managers worldwide. Both results - from Edelman Berland and our studies have identified leadership as the key managerial competency at the moment.

\section{Literature}

500 managerjev največjih slovenskih podjetij [500 managers of the largest Slovenian companies]. (2013, April 2). Manager, p. $10-11$.

Barney, J. (1991). The Resources and Sustained Competitive Advantage. Journal of Management, 17(1), 99-120, http:// dx.doi.org/10.1177\%2F014920639101700108

Bartlett, C.A. \& Goshal, S. (1997). The Individualized Corporation. New York: Harper Business.

Boyatzis, R. E. (1982). The Competent Manager - A Model for Effective Performance. New York: Wiley.

Dierichx, I. \& Cool, K. (1989). Asset Stock Accumulation and Sustainability of Competitive Advantage. Management Science, 35 (12), 1504-1511, http://dx.doi.org/10.1287/mnsc.35.12.1514

Edelman Trust Barometer 2013 Finds a Crisis in Leadership (2013). Available August 24, 2013 from http://www.edelmanberland. com/press-releases/2013-edelman-trust-barometer-finds-a-crisis-in-leadership/

Erpenbeck, J. \& von Rosenstiel, L. (Eds.) (2007). Handbuch Kompetenzmessung. Stuttgart: Schäffer Poeschel.

Heyse, V. (1997). Vorbemerkung: Ziele und Hauptaussagen der Studie. In Heyse, V. (Ed.) Kundenbetreuung im Banken- und Finanzwesen - Praxisbeiträge zur Kompetenzentwicklung, (pp. 1-9), Münster: Waxmann.

Heyse, V. \& Erpenbeck, J. (2004). Kompetenztraining. 64 Informations- und Trainingsprogramme. Stuttgart: Schäffer Poeschel.

Hodgson, G., M. (1998). Evolutionary and Competence-based Theories of the Firm. Journal of Economic Studies, 25(1):25-56, http://dx.doi.org/10.1108\%2F01443589810195606

Hummel, T. R. (2001). Erfolgreiches Bildungscontrolling: Praxis und Perspektiven. Hamburg: Sauer

Jacobs, R. (1989). Getting the Measure of Managerial Competence, Personnel Management, 21( 6): 32 - 37.
Kasper, H., Mühlbacher, J. \& von Rosenstiel, L. (2005). ManagerKompetenzen im Wandel, Zeitschrift Führung + Organisation (zfo,) 74(5), 260 - 264.

Kauffeld, S., Grote, S. \& Frieling, E. (Eds.) (2009). Hanbuch Kompetenzentwicklung. Stuttgart: Schäffer Poeschel.

Knight, F., H. (1921). Risk, uncertainty and profit. New York: Houghton Mifflin.

Lorenzoni, G. \& Lipparini, R.P. (1999). The Leveraging of Interfirm Relationships as a Distinctive Organizational Capability. Strategic Management Journal, 20(4), 317-338, http://dx.doi.org/10.1002\%2F\%28SICI\%291097-0266\% $28199904 \% 2920 \% 3$ A $4 \% 3$ C $317 \% 3$ A \% 3 A A ID SMJ28\%3E3.0.CO\%3B2-3

McCall, M.W. (1998). High Flyers. Developing the Next Generation of Leaders. Boston: Harvard Business School Press.

Mühlbacher, J. (2007). Kompetenzmanagement als Grundlage strategischer Wettbewerbsvorteile. Wien: Linde.

Nelson, R.R. \& Winter, S.G. (1982). An Evolutionary Theory of Economic Change. Cambridge, London: Belknap.

Nohria, N., Joyce, W. \& Roberson, B. (2003). What Really Works. Harvard Business Review, 81(7), 43-52.

Penrose, E.T. (1959). The Theory of Growth of the Firm. London: Oxford University Press.

Prahalad, C.K.\& Hamel, G. (1990). The Core Competence of the Corporation. Harvard Business Review, 68(3), 79-91.

Prahalad, C.K. \& Hamel, G (1994). Competing for the Future. Boston: HBS Press.

Probst, G.J.B, Deussen, A., Eppler, M.J. \& Raub, S.P. (2000). Kompetenz-Management. Wie Individuen und Organisationen Kompetenz entwickeln. Wiesbaden: Gabler.

Sloane, P.F.E. (1998). Funktionen im Wandel: Das neue Verhältnis von Arbeiten und Lernen in einer wissensstrukturierten Praxis. In Franke, N. \& Von Braun, C.-F. (Ed.) Innovationsforschung und Technologiemanagement. Konzepte, Strategien, Fallbeispiele (pp. 89-104), Heidelberg, Berlin: Springer

Sonntag, K. \& Schaper, N. (1999). Förderung beruflicher Handlungskompetenz. In Sonntag, K. (Ed.) Personalentwicklung in Organisationen (2nd Edition) (pp. 211-244), Hogrefe, Göttingen

Stadler, C. \& Wältermann, P. (2012). Die Jahrhundert-Champions. Stuttgart: Schäffer Poeschel.

Teece, D.J., Pisano, G. \& Shuen, A. (1997). Dynamic Capabilities and Strategic Management. Strategic Management Journal, 18(7): 509-533, http://dx.doi.org/10.1002\%2F\%28SICI\%2910970266\%28199708\%2918\%3 A7\%3C509\%3 A\%3 AAIDSMJ882\%3E3.0.CO\%3B2-Z

Woodruffe, C. (1993). What is Meant by a Competence?, Leadership \& Organization Development Journal, 14(1), 29-36, http:// dx.doi.org/10.1108\%2Feb053651

Petra Šparl is an Associate Professor of Mathematics at the Faculty of Organizational Sciences, University of Maribor, Slovenia. Her main research interests are graph theory, data analysis and students' performance in methodological courses.

Anja Žnidaršič is an Assistant Professor of Quantitative Methods at the Faculty of Organizational Sciences, University of Maribor, Slovenia. Her main research interests are social network analysis, micro-enterprises and information-communication technology, and students' performance in methodological courses. 
Helmut Kasper is full professor, Head of the Institute for Change Management and Management Development and Managing Director of the Postgraduate Management Master of Business Administration MBA for Executives, Vienna University of Economics and Business (WU). Professor Kasper's research interests are based on social systems theory, organizational culture, change management, executive education, international and cross cultural management, knowledge and competency management, strategy development and strategy realization.
Jürgen Mühlbacher is Associate Professor at the Institute for Change Management and Management Development, WU Vienna University of Economics and Business. His research interests are strategic management, organizational design, knowledge and competency management, leadership and emerging markets.

Jure Kovač is Professor of Organization and Management at Faculty of Organizational Sciences, University of Maribor. His research interests are organization theory, organization design and management development. 